УДК 811.111'42

DOI: https://doi.org/10.17721/APULTP.2020.40.27-39

\author{
Iryna O. Alyeksyeyeva \\ ORCID ID: 0000-0002-3109-0331
}

\title{
BETWEEN ME, MY YOUNGER SELF AND THE WHOLE WORLD: LETTERS TO ONE'S YOUNGER SELF AS EPISTOLARY GENRE
}

\begin{abstract}
The research treats letters to one's younger (usually teen) self posted on the Internet as epistolary genre marked with peculiar linguistic and pragmatic features. Though the letters to one's self imply intrapersonal communication, i.e. the sender is identical to the addressee, it is not how the sender perceives the situation, which is revealed by the use of pronouns (I for the sender and you for the younger self). However, these two may merge and then we appears to refer to the author's younger and current selves. Another feature of the letters is roles assumed by the addressors. They may occur as a mentor to their rebellious and anxious younger self, which correlates with the purpose of the letter - giving advice. Alternatively, the authors may position themselves as omniscient fortune-tellers who step in in times of trouble to offer support to their teen self by telling what is there to come. Each of the two roles and purposes correlates with specific language means. The mentor role turns the letter into a lesson where the Imperative Mood prevails. The role of a fortune-teller transforms the letter into an autobiographical sketch told in a bizarre way: the author shifts past events into the future with the help of deictic markers (e.g., today, this) and tenses (e.g., future tenses or their synonyms such as constructions to be about to and to be going to). The letters to one's younger self that contain an autobiographical component provide the researcher with an insight into the process of identity construction, since they show how one endows identity with continuity and bridge the divide between one's teen and adult selves. In addition, the letters meant as advice deliver the culture specific idea of what 'a good life' is: they are written to guide their actual intended audience, i.e. Internet (teen) users, in modern society and inform them of true values and right choices.
\end{abstract}

Key words: letter to one's younger self, epistolary genre, communicative event, identity, narrative.

Information about the author: Alyeksyeyeva Iryna Oleksiivna - PhD, associate professor; associate professor of the department of English Philology and Intercultural Communication; Institute of philology; Taras Shevchenko National University of Kyiv.

E-mail: i.alekseeva@knu.ua 


\title{
НАОДИНЦІ 3 СОБОЮ МОЛОДИМ І 3 УСІМ СВІТОМ: ЛИСТИ ДО СЕБЕ МОЛОДОГО ЯК ЕПІСТОЛЯРНИЙ ЖАНР
}

\begin{abstract}
Анотація. У статті листи до себе молодого, розміщені в Інтернеті, розглядаються як епістолярний жанр з характерними лінгвістичними та прагматичними властивостями. Хоча листи до самого себе передбачають внутрішній діалог, в якому адресант тотожній адресатові, иьього не спостерігається в матеріалі дослідження: адресант не вважає себе ідентичним собі молодому, про щзо свідчить використання особових займенників (I - для себе дорослого та уои - для молодого). Однак іноді иі дві ідентичності можуть зливатися в одну, щуо можна побачити у випадках вживання wе. Іншою особливістю листів виявляються ролі, яких набувають автори. Так, адресант може виступати ментором свого бунтівного та тривожного підліткового "я". Метою таких листів є надання поради. В інших випадках автор листа може позиціонувати себе всезнаючим провидием, який з'являється в тяжкі часи для того, щчоб підтримати себе-підлітка розповіддю про те, щуо на нього чекає в майбутньому. Кожна з цих двох ролей та иілей реалізується за допомогою особливих мовних засобів. Роль ментора перетворює лист на урок, де превалює наказовий спосіб. Роль провидия характерна для листів - автобіографічних наративів, які розповідаються у дивний спосіб: автор зсуває минулі подї до майбутнього за допомогою дейктичних маркерів (наприклад, today, this) та дієслівних часових форм (наприклад, майбутні часи або синонімічні конструкиії, такі як to be about to ma to be going to). Листи до себе молодого, які містять автобіографічний компонент, надають дослідникові можливість спостерігати процес побудови ідентичності, оскільки в таких текстах автори намагаються представити свою ідентичність як безперервну, простежуючи ї̈ формування від підліткового віку до моменту написання листа. Крім иьього, листи, призначені для надання поради, містять культурно специфічне розуміння поняття "гарне життя": такі листи пишуться, аби познайомити свою цільову аудиторію, якими насправді $є$ користувачі Інтернету підліткового віку, з сучасним суспільством та його цінностями.
\end{abstract}

Ключові слова: лист до себе молодого, епістолярний жанр, комунікативна подія, ідентичність, наратив

Інформація про автора: Алєксєєва Ірина Олексї̈на - кандидат філологічних наук, доцент; доцент кафедри англійської філології та міжкультурної комунікації; Інститут філології; Київський національний університет імені Тараса Шевченка.

Електронна адреса: i.alekseeva@knu.иa 


\title{
Алексеева И.А.
}

\section{НАЕДИНЕ С СОБОЙ МОЛОДЫМ И СО ВСЕМ МИРОМ: ПИСЬМА К СЕБЕ МОЛОДОМУ КАК ЭПИСТОЛЯРНЫЙ ЖАНР}

\begin{abstract}
Аннотация. $B$ статье письма $\kappa$ себе молодому, размещченные $в$ Интернете, рассматриваются как эпистолярный жанр с характерними лингвистическими и прагматическими особенностями. Хотя письма к самому себе предполагают внутренний диалог, в котором адресант тождественен адресату, это не наблюдается в материале исследования: адресант не считает себя идентичным себе молодому, о чем свидетельствует использование личных местоимений (I - для себя взрослого и уои - для молодого). Однако иногда эти две идентичности могут сливаться в одну, что можно увидеть в случаях употребления местоимения wе. Другой особенностью писем являются роли, принимаемые авторами. Так, адресант может выступать ментором своего бунтарского и неспокойного подросткового "я". Целью таких писем является совет. В других случаях автор письма может позиционировать себя всезнающим провидием, появляюшимся в трудные времена, чтобы поддержать себя-подростка рассказом о том, что ждет его в будущем. Каждая из этих ролей и иелей реализуется с помощью особых языковых средств. Роль ментора превращает письмо в урок, где превалирует повелительное наклонение. Роль провидиа характерна для писем - автобиографических нарративов, рассказываемых достаточно необычно: автор сдигает прошедшие события в будущее $c$ помошью дейктических маркеров (например, today, this) и глагольных временных форм (например, будущие времена или синонимичные конструкиии, такие как to be about to $u$ to be going to). Письма к себе молодому, содержащие автобиографический компонент, предоставляют исследователю возможность наблюдать процесс построения идентичности, поскольку в таких текстах авторы стараются представить свою идентичность как непрерывную, прослеживая ее формирование от подросткового возраста до момента написания письма. Кроме того, письма, задуманные как совет, содержат культурно специифическое понимание понятия "хорошая жизнь": такие письма пишутся, чтобы познакомить иелевую аудиторию, которой являются на самом деле пользователи Интернета подросткового возраста, $c$ современным обществом и его иенностями.
\end{abstract}

Ключевые слова: письмо $\kappa$ себе молодому, эпистолярный жанр, коммуникативное событие, идентичность, нарратив.

Информация об авторе: Алексеева Ирина Алексеевна - кандидат филологических наук, дочент; дочент кафедры английской филологии $и$ 
Актуальні проблеми української лінгвістики: теорія і практика

межкультурной коммуникации; Институт филологии; Киевский национальный университет имени Тараса Шевченко

Электронный адрес: i.alekseeva@knu.иa

The research into epistolary genre is by no means a new field, yet letters to one's younger self seem to be a relatively unexplored area. The Internet abounds in these letters, which results from several factors: firstly, the global web provides ever more people with the chance to express themselves and be heard (more and more celebrities owe their fame primarily to online messages and their audiences are curious to have a glimpse at their biographies and hear them reflect on their life path); secondly, such letters potentially have a therapeutic effect in identity work, because a look back, provided by a letter to one's younger self, may help people to reconcile themselves with their past, to embrace the present and, finally, to uncover continuity of their identity.

Thus, letters to one's younger self (in fact, letters to a self of any age) constitute a very specific type of communication that evokes interest and requires comprehensive analysis within the framework of pragmatics, psycholinguistics, communicative linguistics, media linguistics, sociolinguistics and linguistic anthropology, which stipulates the topicality of the research. The purpose of the article is to make an attempt at investigating this genre, identify its specific features and language means used to verbalize them.

The scientific novelty of the study arises from the analysis of letters to one's younger self as a communicative event that becomes an arena for a peculiar configuration of participants, intricate identity construction and time shifts.

The object of the research is a communicative situation created by authors of letters to their younger selves. The subject of the investigation is language means that re-occur in this genre and help authors to achieve their communicative goals and, therefore, may be regarded as characteristic features of this epistolary genre.

The material of the study consists of eight letters to one's younger self that appeared in the Internet English-speaking segment within the period from 2016 to 2019 . 
The notion of genre is essential for the research, so it requires a clear-cut definition. In this paper, genre is interpreted as 'one order of speech style, a constellation of systemically related, cooccurrent formal features and structures that serves as a conventionalized orienting framework for the production and reception of discourse' [1, p.79].

The study of letters to one's younger self may be carried out efficiently only if a researcher combines at least two approaches. Firstly, one should make use of investigations into epistolary literature (see, for example, [7; 8]). Secondly, one will inevitably feel the need to refer to studies into autobiographical narratives, which brings up the issues of identity and its continuity [5], temporal aspects of narration [12;13], functions of autobiographical narratives for the narrator's psyche as well as the correlation between autobiographical narrative and culture $[3 ; 6: 16]$.

To analyse a communicative event, it is necessary to identify its participants and their relationship. The letters selected for the sample are written by the authors, aged from 24 to 40 , to their 14-17-year old selves. Thus, at first glance, the addressor is supposed to merge with the addressee, which implies intrapersonal communication. Yet, a more careful study into the letters reveals the assumption that the addressor and the addressee are far from being identical, and it is not only because the letters start with the Dear + addressee's name formula, which may be done due to the traditional format (it should be mentioned, though, that one letter in the sample starts with Dear 17-year-old self [2] and another with $\mathrm{Hi}$, 14-year-old me [14], i.e. the authors explicitly indicate the 'circular' nature of communication). In some of the letters, the authors position themselves as just a little bit different (namely, older and wiser) than their teen selves. This peculiarity is found in Terrence Thomas' opening phrase I am essentially still you, only I am a little older and wiser [15]. Some authors admit a drastic difference between their younger and current selves and, consequently, predict difficulty convincing the addressee that they are the same person, e.g. How can I prove it's really me? [11]. It is important to note that the relationship between the authors and their younger self is grounded 
on the older self's acceptance of the younger self: the writer is fully aware of and accepts all the drawbacks, anxieties and troubles of the teenage, while anticipating resistance and mistrust from the teen self.

This assumption gives ground to a specific configuration of roles: the author becomes a mentor, a teacher, an advisor (Leolin Bowen even lays out her letter as numbered lessons (Lesson \#1, Lesson \#2 etc. [2], Melanson also defines his writing as didactic: I won't spoil the lesson with a full explanation (you'll have to learn that one on your own)[11]), while the young addressee turns into a student receiving instructions unwillingly (Btw, we're quite stubborn and it's possible you won't listen to the advice below [9]; Take this with a grain of salt, this isn't black-and-white advice. You and I both know that you wouldn't listen anyways, you'll have to fill in the colors yourself [11]). Here, the writers use personal pronouns $I$ and you to make themselves and their younger selves distinct and the modal verb won't emphasizes the teen's reluctance to follow any advice.

The phrase we're quite stubborn in [9], namely the pronoun we, points out a different configuration of participants that co-exists with the previous self-positioning in the same sentence. Consider also the following: Here are some other things you should probably know. I have had tons of experience with relationships by now. I have gotten married, birthed a child (I know! I know! We said that we would never have children...) [2]). In both cases, the authors are quite distinct from their young selves in one part of their message and therefore use first and second person pronouns $I$ and you, yet these two selves merge into we in the other part of this very paragraph.

The purpose of the communicative event is tightly bound with the participants' 'mentor' and 'student' roles: first and foremost, it is giving advice, which is often stated explicitly and which will not be eagerly received: I provide you with some advice that might help you to become \#WORLDREADY. (...) I know you're not going to take much notice of what I'm writing [10]. This purpose stipulates the language means used in the letters: these are a peculiar bullet point layout (...we think in bullet points and absorb content best in the form of bullet points, so here goes... [9]), the Imperative Mood (Learn to push your own buttons. Inspire yourself [9], Believe in 
yourself... Do your best... Have respect for other people [10], Never ever, ever, ever dim your light... Please forgive yourself [2], Try to see things from your parents' point of view and learn how to balance that with yours [14], Be true to yourself... Try not to take this personally [14], Don't wait... Don't think your first has to be your last [14]). J. Melanson's letter stands out among the others because one finds here numerous examples of the Imperative combined with explicit mentoring in the repetitive That's called + Noun construction, emphasized with the help of the bold type: ...don't ever lose touch with that fire in your belly, that's called passion... Also, do you remember how you felt when your buddy Vinny moved away and you hardly ever saw him again or kept touch? That's called regret [11]. The construction in bold resembles very much the way a parent explains a child meanings of words.

Offering advice is not the only peculiarity of letters to one's younger self, just like being a mentor is not the only role acted out by the author. Another purpose for writing the letter is to support one's younger self at a certain turning-point. The turning-point may be a loss of a parent (which is the case with Terrence Thomas: Of all the times I could have gone back to, I chose this particular time, because this was the time that you needed me the most.... This year has been particularly tough on you. 6 months ago you buried your mother. But you don't allow yourself to properly mourn [15]), or an important event such as graduation (As you are getting ready to graduate high school and head off to college, I hope that I can relay some wisdom to you to make these next few years (and decades) a little less painful [2]), or just a situation in the past that might have gone unnoticed by others but exposed something important to the writer about her own identity, e.g. cultural identity (Today at school everyone laughed at me because I said pomangranate. Apparently it's pomegranate. Ammi and Appachchi say pomangranate???? So embarrassing [14]), racial identity (School was decent. Went over to see Nina after school and on the way the year nine "fan club" just got at it! "Look at you, er, what's up with her hair?" [14]), or sexual identity (You are 16 when you first fall in love with a girl. It is an intoxicating, allconsuming feeling. You have never been particularly shy when it 
comes to dating, but you've never wanted someone to like you back as much [14]). In these passages, the authors leave the role of a mentor and turn into a narrator. The effect is achieved with the help of past tenses (was, buried, went) or the so-called historical present (has been, are getting ready, are) as well as of deictic words that bring the past into the present (today, these).

The purpose of such letters is to offer psychological support and solace. To achieve this effect, the authors tend to build their strategy in the following way: they shift past into the present, depict a traumatizing situation and then assume the role of a fortune-teller of a specific type: they tell the story of what happened afterwards but use the you will + verb and to be going to constructions, i.e. they present the narrated past events as those yet to come, e.g.

In third grade, you will be put in a 'special' reading and writing class because you're not quite performing up to par with your classmates... Your career is going to take off... [9]; You're going to experience amazing things... Almost everything worthwhile you will go on to do in your life will happen by accident - and when you least expect it... You will grow... Let me reassure you. You will be as tall as them when you're 17... [10], You will become a writer. Which doesn't sound exciting at 20, but you're just going to have to trust me. It will be tough in the beginning. You will struggle to find your voice. You will doubt yourself. You will see your writer peers excel and wonder if you have what it takes. Repetition will be your hallmark. But at some point, everything will click. You will discover that you have an unique ability to selflessly give yourself in everything you write. You will find that your art is also a form of therapy for you. It will feel celestial. People will cling to your words and apply them to their own lives [15]; ...you will eventually get tired and become resentful of them and yourself for not living your wonderful, authentic life [2]; You'll be pleased to hear that despite the many, many mistakes you'll make, you'll do a decent job at navigating the grownup world [14].

Yet, the future tense and other grammatical means expressing futurity are not the only ways to make predictions. Leolin Bowen, for 
example, provides a brief account of her past with the help of the Imperative mood:

Leolin, you are about to embark on a journey that you will be talking about and remembering for the rest of your life, so spend these next years enjoying it. Learn, grow, travel, challenge yourself, try out for that play, meet different types of people, date outside your "type", save \$\$, pay off debt, fail, succeed, and from all those experiences will come the self-confidence that will draw you to the person that is for you [2].

All in all, the time shift entails at least two phenomena: it endows the author with the role of an omniscient narrator, almost a prophet and, by doing so, it turns a letter into a sketchy autobiography. And here we have to face the following questions: Are these letters written only to one's younger self? Is the younger self the only beneficiary of this communicative event?

Since what we find in the letters is the authors' autobiography, analysis of this genre will not be complete if we overlook the features it shares with autobiographies, which may be defined as 'an account, given by a narrator in the here and now, about a protagonist bearing his name who existed in there and then' [5, p.250]. Narrative about oneself is 'a story that simultaneously is about the past, the present, and the process in which both merge' [3, p.250]. The letters, just like any autobiographical narratives, contain 'two main temporal perspectives: One that opens up from the present to the past, yet it does so in a way that, in the end, the present fits coherently in with the other perspective, which, in its turn, represents the life course as projected along (more or less) chronological dimension (...). One astonishing effect often emerging from such constellation is that one's life, once shaped and sequentially ordered as a narrative event, appears as a kind of development towards a certain goal' [3, p.251]. The letters of the sample are written by successful people in their prime and addressed to themselves when they were most vulnerable or uncertain about who they were and what they were to do, so it is natural to suggest that by writing a letter to their younger self, the now content authors try to build a bridge between their teen self and 
their adult self as well as to convince themselves that by the time the letter is being written they have resolved some important psychological and/or philosophical issues and that, therefore, their lives do have meaning.

However, it is not only the authors' personal psychological plateau that we may observe. The researchers argue that 'autobiographical narratives... are useful vehicles for exploring not only ethical dimensions of identity construction but also the ethical fabric of the social worlds in which they emerge' [6, p.77]. There seems to be another beneficiary to the letters and these are mass audience to whom the writer, who rests on the laurels of achievement and success, wants to communicate what 'a good life' is. Consider the following passages:

A husband will not save you, and marriage is not the end. I know because you got it. The wonderful husband. The beautiful wedding ring. The cute baby. You two looked good in pictures. You got to be a stay-at-home wife and mother. It bored the fucking hell out of you. And you know why? You spent so much time working on gaining the life that you were told was important. "Just find a rich husband," you can hear your mother saying. But the problem is that you spent so much time trying to be what a "good man" wanted that you didn't know what you wanted and you got lost [2]; Make family a priority. I didn't attend my grandmother's funeral because I had a business trip that was "critical to my career'. We are one of 19 grandchildren and only two of us didn't make it to the funeral. To this day, I don't remember what that very important "careeraltering" opportunity was. Show up for family. It matters [9]; when you start dating women you'll encounter cultural blockages along the way, unwanted attention from public and even, at times, interrogation from strangers. You'll feel crushed when your grandmother asks, "Do you think that is natural?" The question will replay in your mind [14].

These passages are addressed to readers and here the authors refute conventional ideas of 'a good life' (such as Cinderella story, career woman story, or heterosexual relations) that prescribe an appropriate life script. The authors of the letters insist that there are 
alternative paths to success and contentment in modern society and they offer themselves as examples. By doing so, they both reflect and generate social and cultural changes.

Conclusion. The analysis of the sample has revealed that letters to one's younger self are messages created in a specific communicative event and contain permanent features that turn them into a genre.

The first peculiarity is the configuration of participants. In a letter to one's younger self, the addressor and the addressee are the same person but at different period in life, so the addressor alternates between the personal pronouns $I$ and you to refer to themselves in the past and by doing so emphasizes the differences between the younger and older selves. Yet, these two may merge and this is marked by the pronoun we.

The relation between the two distinct selves is not reciprocal: the older self embraces the younger self, whereas the younger self is rebellious and wary of any, even benevolent, intrusion. The perceived psychological divide is made deeper because of the addressor's role of a mentor whose objective is to give advice and help the addressee through the hurdles of the teen age. To achieve this, the authors resort to imperative sentences. In addition, they use a more subtle tactic, which makes letters similar to autobiographies: the authors tell how they dealt with the challenges of their teen years. This tactic is mostly carried out with the help of a time shift: the author talks about events in the past using either the historical present or, more often, by using the future tenses or their synonyms (e.g., to be about to, to be going to) as well as deictic expressions that place past events or actions into the present (today, this, here). This tactic transforms the author's role into that of an omniscient fortune-teller.

The autobiographic component reveals an important psychological function performed by letters to one's younger self: looking back and recounting the past helps authors to uncover the connection between their teen self with their current self and, by doing so, the authors construct their continuous identity. 
Another addressee of letters to one's younger self is the Internet audience who, just like the younger self, receive direct guidance and also are offered a real-life story of how an anxious teenager, facing challenges and coping with anxiety, finds a way to success and happiness. Studied from this point of view, letters to one's younger self may provide a researcher with a valuable insight into culture specific meaning of 'success', 'happiness' and 'a good life' as well as understand psychological, social and cultural changes one faces within ten or twenty years of one's life.

\section{REFERENCES}

1. Bauman, R. (2001). Genre. Key Terms in Language and Culture. Malden, MA: Blackwell Publishing Ltd., 79-82 [in English].

2. Bowen, L. (2018). A Letter to My Younger Self. URL: https://ravishly.com/letter-my-younger-self (last access: 24.01.2020) [in English]

3. Brockmeier, J. (2001). From the end to the beginning. Retrospective teleology in autobiography. Brockmeier, J. \& Carbaugh, D. (Eds.). Narrative and Identity: Studies in Autobiography. Self and Culture. Amsterdam/Philadelphia: John Benjamins Publishing Company, 247-282 [in English].

4. Fivush, R. \& Pasupathi, M. (2019). Silencing Self and Other through Autobiographical Narratives. Murray, A. (Ed.). Qualitative Studies of Silence. KwaZulu-Natal, South Africa: Cambridge University Press, 126146 [in English].

5. Freeman, M. (2001). From substance to story. Narrative, identity, and the reconstruction of the self. Brockmeier, $J$ \& Carbaugh, D. (Eds.). Narrative and Identity: Studies in Autobiography. Self and Culture. Amsterdam/Philadelphia: John Benjamins Publishing Company, 283-298 [in English].

6. Freeman, M., \& Brockmeier, J. (2001). Autobiographical identity and the meaning of the 'good life'. Brockmeier, J. \& Carbaugh, D. (Eds.). Narrative and Identity: Studies in Autobiography. Self and Culture. Amsterdam/Philadelphia: John Benjamins Publishing Company, 75-99 [in English].

7. Hanscombe, E. (2012). Letters to Nietzsche. Axon: Creative exploration, 1 (2). URL: https://www.axonjournal.com.au/issue-2/lettersnietzsche (last access: 24.01.2020) [in English]. 
8. Lake, R. (2012). Letters as Windows into a Life of Praxis: Using the Epistolary Genre to Explore the Tensions between the Private Self and Public Action. Malot, C., Porfilio, B. \& Kress, T. (Eds.). Challenging status quo retrenchment: New directions in critical qualitative research. Charlotte, NC: Information Age Publishers. URL: https://www.academia.edu/189069 (last access: 24/01/2020) [in English]

9. Martin, A.J. (2016). A Letter to My Younger Self. URL: https://byrslf.co/a-letter-to-my-younger-self-24dc186932c2 (last access: 24.01.2020). [in English].

10.May, J. (2018). A Letter to My Younger Self. URL: https://www.worldready.org/news/john-may/ (last access: 24.01.2020) [in English].

11. Melanson, J.P. (2018). Dear Knucklehead: A Letter to My Younger Self. URL: https://psiloveyou.xyz/dear-knucklehead-a-letter-to-myself-inhigh-school-d8ecd56adb54 (last access: 24.01.2020) [in English].

12. Ochs, E. (2004). Narrative Lessons. Duranti, A. (Ed.). A Companion to Linguistic Anthropology. Blackwell Publishing Ltd., 269-289 [in English].

13. Pavlenko, A. (2007). Autobiographic Narrative as Data in Linguistics. Applied Linguistics, 28(2), 163-188 [in English].

14. Theminimulle, S., Arboine, N. \& Little, L. (2019). 'Don't pretend to be something you're not': a letter to my teenage self. The Guardian. June 1, 2019. URL: https://www.theguardian.com/society/2019/jun/01/a-letter-tomy-teenage-self-gal-dem\#comments (last access: 24.01.2020) [in English].

15. Thomas, T. (2017). A Letter to My Younger Self. URL: https://www.huffpost.com/entry/a-letter-to-my-youngerself_b_58c4380ee4b0a797c1d39d4f (last access: 24.01.2020). [in English].

16. Wierzbicka, A. (2005). In Defense of 'Culture'. Theory \& Psychology, 15(4), 574-597 [in English]. 